\title{
Study of Decolouration Effect on Denim by Ceric Sulphate Treatment using Statistical Modeling
}

\author{
Sanjay Katode, Saptarshi Maiti, Santosh Biranje and Ravindra V Adivarekar* \\ Department of Fibres and Textile Processing Technology, Institute of Chemical Technology, India
}

*Corresponding author: Ravindra V Adivarekar, Department of Fibres and Textile Processing Technology, Institute of Chemical Technology, Matunga (E), Mumbai-400019, Maharashtra, India

submission: 棘August 01, 2018 Published: 非 August 14, 2018

\begin{abstract}
By 2021, global denim market is anticipated to grow over 900 million pieces. 70\% denim wears have localized decolouration effect of spray look, produced conventionally by Potassium permanganate. But Potassium permanganate is toxic when high concentration of manganese gets released through the effluent into an ecosystem and has potential environmental risks. To create diversity in denim fabrics it is necessary to apply special techniques and new substances. In this study, denim was treated with ceric sulfate to obtain the desired effect. Design of Experiments (DoE) had been used to optimize the concentration of ceric sulfate. Colour strength measurement in terms of $\mathrm{K} / \mathrm{S}$ of sprayed denim with Potassium permanganate and ceric sulfate were compared. Physical and mechanical properties of such treated fabrics were investigated along with colour fading, like bending length, crease recovery angle, tear and tensile strength measurements. The results show that ceric sulfate could be a suitable alternative to Potassium permanganate with comparable decolouration effect.
\end{abstract}

Keywords: Denim; Decolouration; Potassium permanganate; Ceric sulfate; Design of Experiments

\section{Introduction}

Denim is everybody's fabric. This category has inspired strong opinions from historians, teenagers and movie stars, and has acquired different styles over the years [1]. The market is expected to keep on growing over $6-7 \%$ pa on an already large base creating a huge market of over 900 million pcs. of denim by 2023 [2]. Currently, India is the second largest consumer of denim apparels after China. Original solid blue colour is not attractive to the consumers and hence many manufactures are trying to remove part of the blue colour from the denim fabric surface [3]. The decolouration effect of spray look can be achieved by oxidized indigo to produce a light part or the very popular 'used look'. To achieve such effect, over $70 \%$ of denim wears have to undergo a partial bleaching process [4]. Number of chemicals and processes such as Potassium permanganate $\left(\mathrm{KMnO}_{4}\right)$, Sodium hypochlorite ( $\mathrm{NaOCl})$, Hydrogen peroxide $\left(\mathrm{H}_{2} \mathrm{O}_{2}\right)$, Organic peroxides and Laccase enzyme are commonly used for denim decolouration and are available for generating this effect [5]. However, except Potassium permanganate method, no other method has gained popularity. Thus, there is still a room for exploring newer techniques to achieve the very effect.

Every day worldwide, more than 3tons of Potassium permanganate is consumed which is a non-eco-friendly discharging chemical going into the waste water. It is a strong oxidizing agent but with high risks for the environment and health [6]. During application, high amounts of manganese based products get released into the effluent, which are very toxic in high concentration. Manganese flows via waste water into the surface and ground water. Plant extracts manganese from the ground and transport into the leaves. Extreme high concentration results into withering of leaves and in this way high amount of manganese comes into the food chain [7]. The spray treatment with Potassium permanganate is the most economical and traditional method [8]. It is an effective procedure but having risks to the environment and health with high aquatic toxicity. In many countries there are strict regulations or even an obligation to provide evidence for avoiding such misuse of it. To create diversity in the denim fabrics it is necessary to apply special techniques and new substances to respond towards a huge market demand [9].

Cerium is a lanthanide metal and member of the rare earth metals. It is the most abundant and after europium, a reactive rare earth metal [10]. Cerium salts, especially ceric sulfate, are often used as a standard reagent for volumetric analysis in cerimetric titrations [11]. In certain volumetric analysis, Potassium permanganate has been replaced with ceric sulfate [12]. Ceric sulfate is an oxidizing agent which has not yet been explored in textile processing sectors. It does not contain any hazardous materials with biological limits and not persistent. In this study we have studied potential alternative for Potassium permanganate with ceric sulfate using a Design of Experiment (DoE) model to establish the optimized concentration of ceric sulfate, $\mathrm{pH}$ and time of treatment. 


\section{Experimental}

\section{Materials and chemicals}

Indigo dyed denim fabric was provided from Century Denim. It comprised of $100 \%$ cotton, having 285 GSM (gram per sq. metre), with twill weave $(3 / 1)$ construction, thread density $64 \times 46$, count 10x 9 Ne. Lava Zyme AEN 01 (Amylase based Desize), and Lava Sperse KDS conc. (Anti-back staining agent) were supplied by Dystar India Pvt. Ltd. Potassium permanganate and Ceric sulfate were procured from SD Fine chem Ltd.

\section{Methods}

Preparation: The most widely used scraping method of denim i.e., the hand scraping method was used for scraping process. The fabric samples were placed on an inflated air tube and emery paper was used to scrap the fabric. After scraping, Potassium permanganate and different concentrations of ceric sulfate solutions were sprayed on indigo dyed denim fabrics with the help of a spray gun.

Desizing: Desizing was conducted in liquor containing Lava Sperse KDS conc. (0.5g/l), Lava Zyme AEN 01 (1g/l) and material to liquor ratio (MLR) of 1:20 in an industrial horizontal sample washing machine (Ramson, India) at temperature $40{ }^{\circ} \mathrm{C}$ for $15 \mathrm{~min}$. After treatment was given in terms of hot wash $\left(60^{\circ} \mathrm{C}\right)$ followed by normal wash $\left(35^{\circ} \mathrm{C}\right)$.

Hydro-extraction and drying: Processed denim was squeezed in a laboratory scale hydro-extractor machine (Ramson, India) at 200rpm for $2 \mathrm{~min}$ and dried in a tumble drier (Ramson, India) at 75 ${ }^{\circ} \mathrm{C}$ for $40 \mathrm{~min}$.

Experimental Design: The concentration of ceric sulfate, $\mathrm{pH}$ and time were optimized using response surface methodology (RSM). RSM produces an empirical polynomial model which gives an approximation of the true response surface over a factor region $[13,14]$. The response investigated was the \% reduction in K/S which represents decolouration performance. The Box-Behnken design (BBD) was analyzed by design expert ${ }^{\circledR} 6.0$ software (StatEase, Inc.). The ranges chosen for the factors are shown in Table 1.

Table 1: Factors and ranges for BBD study of the concentration of Ceric sulfate, $\mathrm{pH}$ and time.

\begin{tabular}{|c|c|c|}
\hline Name & Lower Limit & Higher Limit \\
\hline A. Ceric sulfate (\%) & 0.50 & 2.25 \\
\hline B. pH & 0.50 & 2.00 \\
\hline C. Time (min) & 5 & 10 \\
\hline
\end{tabular}

Testing and analysis: Product performances of the treated denim fabrics were tested using a H5KS Single Column Universal Tester (Tinius, Olsen), Tear Strength tester (Rossari Labtech, India), Stiffness tester (Rossari Labtech, India), Computer Color Matching (Premier Color Scan 5100), Crease Recovery Angle Tester (Rossari
Labtech, India) and GSM cutter (Rossari Labtech, India). Prior to testing, all the samples were conditioned at $65 \%$ relative humidity and at $27^{\circ} \mathrm{C}$ for 24 hours [15].

Tensile strength and elongation at break were determined using fabric strength tester according to ASTM D 5034 (2009). Tear Strength was measured as per ASTM D 1424-9 test method. Stiffness was measured in terms of bending length of fabric using stiffness tester according to BS 3356 (1990). Crease Recovery Angle was measured according to the standard IS 4681-1981. Weight loss (\%) in fabric was calculated from the difference in fabric weight (GSM) before and after the treatment according to ASTM D 3776 (1996). Moisture regain and moisture content (\%) were calculated from the difference in total fabric weight and oven dry weight according to ASTM D 1909 (2004) [16].

\section{Results and Discussion}

\section{Concentration of ceric sulfate}

Decolouration effect on indigo dyed denim fabric is generally produced by application of oxidizing agents. In denim industry, Potassium permanganate is widely used at concentrations around $1-2 \%$ to get a good decolouration effect. The preliminary trials with ceric sulphate in the same range of application concentration reveals that, at nearly $1.375 \%$ concentration of ceric sulfate, the decolouration effect is almost similar to that of $1 \%$ concentration of potassium permanganate. Concentrations of ceric sulfate hence were taken in the range of 0.5 to $2.25 \%$, and further experimentation was carried out through the design of experiments.

\section{pH}

Initially the $\mathrm{pH}$ was adjusted to get a clear solution of ceric sulfate so that it could be easily applied by spray method. Above $\mathrm{pH}$ 2 , solution of Ceric sulfate becomes turbid and forms precipitation that disturbs the desired decolouration effect on indigo dyed denim fabric. Hence the $\mathrm{pH}$ of the solution was optimized in the range 0.5 to 2 .

\section{Time}

In conventional method of drying, the sprayed indigo dyed denim fabric is dried for $5-10 \mathrm{~min}$. Thus, after spraying ceric sulfate solution, the denim fabric was dried at room temperature for 5 to $10 \mathrm{~min}$.

\section{Factors affecting decolouration effect on indigo dyed denim fabric}

Experiments for the decolouration effect on indigo dyed denim fabric were performed using the design matrix given in Table 2. Statistical analysis is done by the Fisher's F test for analysis of variance (ANOVA) and the results are tabulated in Table 3. F value of 27.65 implies the model is significant. There is only a $0.01 \%$ chance that F Value this large could occur due to noise. A Prob $>$ F less than 0.0500 indicates that the model terms are significant. In this case A, $\mathrm{A}^{2}, \mathrm{~B}^{2}, \mathrm{C}^{2}, \mathrm{AC}$ are significant model terms. A Pred R-Squared of 0.9123 is in reasonable agreement with the Adj R-Squared of 0.9375. Adeq Precision measures the signal to noise ratio. A ratio greater than 
four is desirable. The ratio of 17.036 indicates an adequate signal. This model can be used to navigate the design space.

Table 2: Design matrix for decolouration effect on indigo dyed denim fabric.

\begin{tabular}{|c|c|c|c|c|}
\hline Run & Ceric sulfate (\%) & $\mathbf{p H}$ & Time (min) & $\mathbf{K / S}$ \\
\hline 1 & 1.375 & 2 & 10 & 4.1301 \\
\hline 2 & 2.25 & 2 & 7.5 & 4.4473 \\
\hline 3 & 1.375 & 0.5 & 10 & 4.4836 \\
\hline 4 & 1.375 & 2 & 5 & 4.1406 \\
\hline 5 & 2.25 & 1.25 & 5 & 4.0952 \\
\hline 6 & 1.375 & 1.25 & 7.5 & 3.681 \\
\hline 7 & 0.5 & 2 & 7.5 & 5.1104 \\
\hline 8 & 1.375 & 1.25 & 7.5 & 3.681 \\
\hline 9 & 1.375 & 1.25 & 7.5 & 3.681 \\
\hline 10 & 0.5 & 0.5 & 7.5 & 5.0642 \\
\hline 11 & 2.25 & 0.5 & 7.5 & 4.321 \\
\hline 12 & 0.5 & 1.25 & 5 & 5.9273 \\
\hline 13 & 0.5 & 1.25 & 10 & 5.1661 \\
\hline 14 & 1.375 & 0.5 & 5 & 4.5146 \\
\hline 15 & 2.25 & 1.25 & 10 & 4.7644 \\
\hline 16 & 1.375 & 1.25 & 7.5 & 3.681 \\
\hline 17 & 1.375 & 1.25 & 7.5 & 3.681 \\
\hline
\end{tabular}

\begin{tabular}{|c|c|c|c|c|c|}
\hline $\mathrm{A}$ & 1.65629 & 1 & 1.65629 & 61.9461 & 0.0001 \\
\hline $\mathrm{B}$ & 0.0385 & 1 & 0.0385 & 1.44004 & 0.2692 \\
\hline $\mathrm{C}$ & 0.00223 & 1 & 0.00223 & 0.08332 & 0.7812 \\
\hline $\mathrm{A}^{2}$ & 3.13496 & 1 & 3.13496 & 117.249 & $<0.0001$ \\
\hline $\mathrm{B}^{2}$ & 0.15497 & 1 & 0.15497 & 5.79612 & 0.0469 \\
\hline $\mathrm{C}^{2}$ & 0.83145 & 1 & 0.83145 & 31.0966 & 0.0008 \\
\hline $\mathrm{AB}$ & 0.0016 & 1 & 0.0016 & 0.05999 & 0.8135 \\
\hline $\mathrm{AC}$ & 0.51151 & 1 & 0.51151 & 19.1308 & 0.0033 \\
\hline $\mathrm{BC}$ & 0.00011 & 1 & 0.00011 & 0.00393 & 0.9518 \\
\hline Residual & 0.18716 & 7 & 0.02674 & & \\
\hline $\begin{array}{c}\text { Lack of } \\
\text { Fit }\end{array}$ & 0.18716 & 3 & 0.06239 & & \\
\hline $\begin{array}{c}\text { Pure } \\
\text { Error }\end{array}$ & 0 & 4 & 0 & & \\
\hline \begin{tabular}{c} 
Cor Total \\
\hline
\end{tabular} & 6.8415 & 16 & & & \\
\hline
\end{tabular}

\section{Regression analysis}

In order to model decolouration effect and predict performance for different sets of experiments, a simple equation regression analysis is undertaken. The sign of each coefficient indicates its positive/negative effect in the overall formulation. The response is expressed in form of regression Equation 1 as,

$\mathrm{K} / \mathrm{S}=+3.68-0.46^{*} \mathrm{~A}-0.069 * \quad \mathrm{~B}-0.017 * \quad \mathrm{C}+0.86^{*} \mathrm{~A}^{2}+0.19 *$ $\mathrm{B}^{2}+0.44^{*} \mathrm{C}^{2}+0.020^{*} \mathrm{~A} * \mathrm{~B}+0.36 * \mathrm{~A} * \mathrm{C}+5.125 \mathrm{E}-003^{*} \mathrm{~B}^{*} \mathrm{C}$

Where, the factors $\mathrm{A}, \mathrm{B}$, and $\mathrm{C}$ represent the concentration of ceric sulphate, $\mathrm{pH}$ and time respectively.

Table 3: ANOVA results for $\%$ reduction in $\mathrm{K} / \mathrm{S}$.

\section{Response surface plot}

The effects of the significant factors influencing reduction in K/S on decolouration effect are shown in Figure 1-3 as response surface plots. The design points for optimization of Ceric sulfate concentration, $\mathrm{pH}$, and time are $1.38 \%, 1.25,7.5 \mathrm{~min}$ respectively.

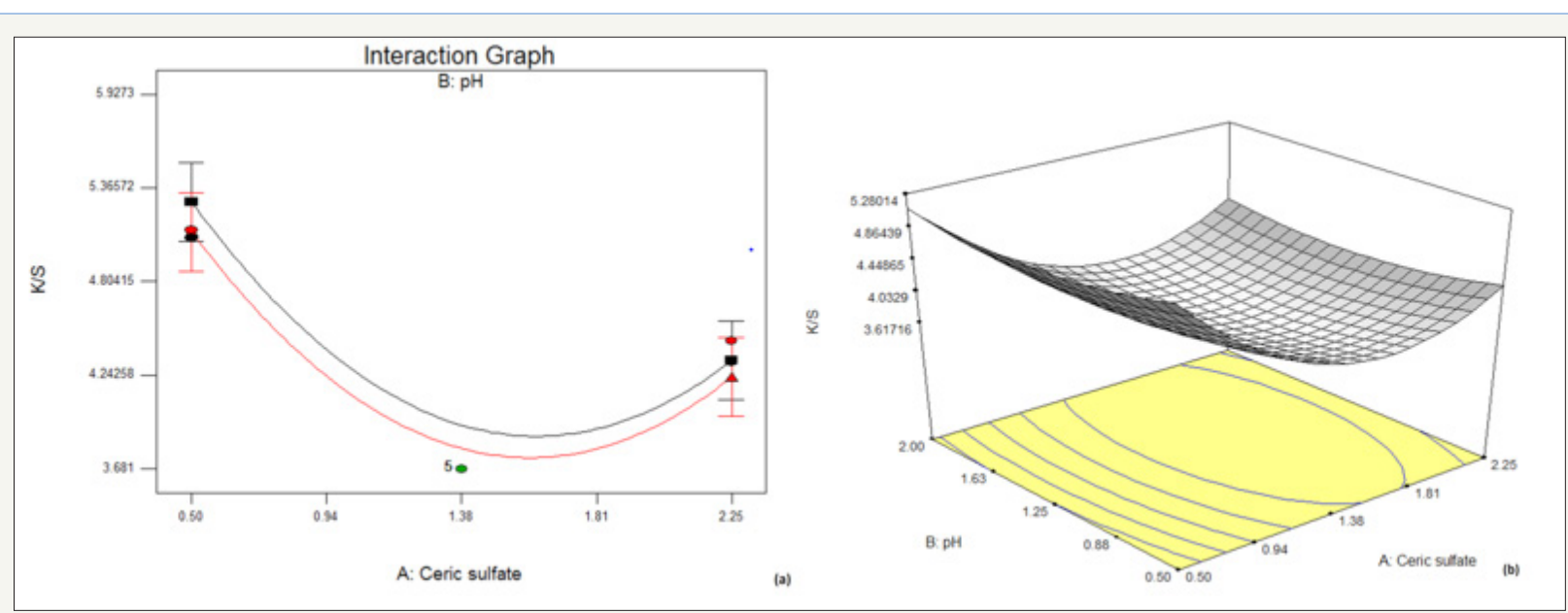

Figure 1: Effect of concentration of ceric sulphate and $\mathrm{pH}$ on $\%$ reduction in K/S (a) interaction graph (b) response surface plot.

Figure 1 illustrates that with the increase in concentration of Ceric sulfate there is an initial decrease in $\mathrm{K} / \mathrm{S}$, after certain amount of which results in an increase in K/S. This effect is observed to be same over the entire range of $\mathrm{pH}$ taken. It indicates that higher the 
$\mathrm{pH}$, lower is the $\mathrm{K} / \mathrm{S}$ and vice versa. The optimum concentration range for decolouration with ceric sulfate is 1.38 to 1.81 . Beyond concentration of around 1.81, the solution slowly decomposes depositing the light-yellow cerium dioxide [17] due to oxidation of ceric sulfate at higher concentration.

In Figure 2, it has been observed that when there is an increase in the concentration of ceric sulfate, the $\mathrm{K} / \mathrm{S}$ initially decreases up to a certain amount of its concentration, and further increases beyond it. It may be attributed to the fact that ceric sulfate starts oxidizing in solution at higher concentration. This effect is observed to be same up to a certain point of time. With higher the time of drying, greater is the discharging effect by the ceric sulfate thereby resulting in lower K/S and vice versa. But this desired effect is not observed at higher concentration range which may be a result of oxidation of Ceric sulfate dominating over the effect of time on decolouration.

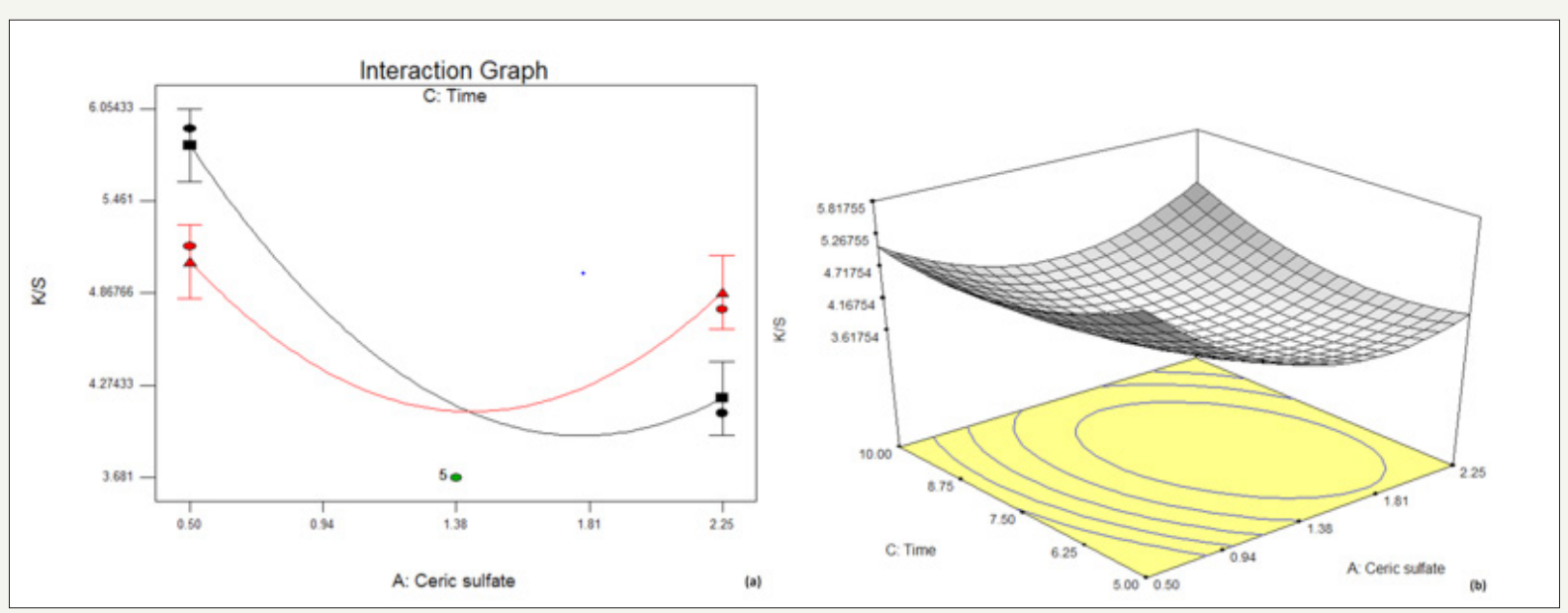

Figure 2: Effect of concentration of ceric sulfate and time on \% reduction in K/S (a) interaction graph (b) response surface plot.

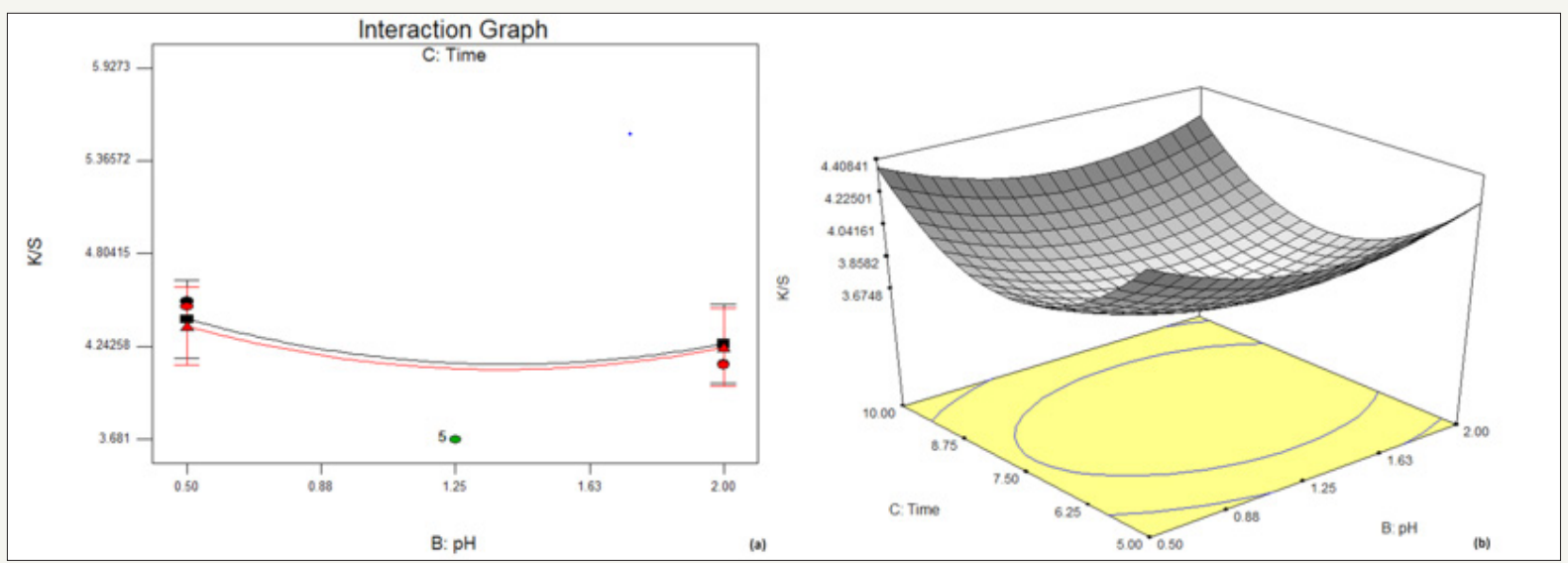

Figure 3: Effect of $\mathrm{pH}$ and time on \% reduction in $\mathrm{K} / \mathrm{S}$ (a) interaction graph (b) response surface plot.

In Figure 3, it has been observed that with the increase in time of drying, $\mathrm{K} / \mathrm{S}$ decreases over the entire range of $\mathrm{pH}$, thereby

resulting into a greater decolouration effect with higher drying time. However, with the rise in $\mathrm{pH}$, the overall $\mathrm{K} / \mathrm{S}$ decreases.

\section{Numerical optimization of responses}

Table 4: Range of input parameters and response.

\begin{tabular}{|c|c|c|c|c|c|c|}
\hline Constraints Name & Goal & $\begin{array}{l}\text { Lower } \\
\text { Limit }\end{array}$ & $\begin{array}{l}\text { Upper } \\
\text { Limit }\end{array}$ & $\begin{array}{l}\text { Lower } \\
\text { Weight }\end{array}$ & $\begin{array}{l}\text { Upper } \\
\text { Weight }\end{array}$ & Importance \\
\hline Ceric sulfate (\%) & is in range & 0.50 & 2.25 & 1 & 1 & 3 \\
\hline $\mathrm{pH}$ & is in range & 0.50 & 2.00 & 1 & 1 & 3 \\
\hline Time (min) & minimum & 5 & 10 & 1 & 1 & 3 \\
\hline $\mathrm{K} / \mathrm{S}$ & minimum & 3.681 & 5.9273 & 1 & 1 & 3 \\
\hline
\end{tabular}


In multi response optimization, desirable weightage can be given to all responses and a combined influence of all responses and desirability can be determined by varying values of input parameters. Table 4 shows the range of input parameters and that of responses with the goal and weights assigned to each parameter. The optimized solutions with desirability are presented in Table 5.

Table 5: Solution to the range of input parameters and response with desirability.

\begin{tabular}{|c|c|c|c|c|c|}
\hline Solution No & CS & $\mathbf{p H}$ & Time & Desirability & K/S \\
\hline Experiment No.1 & 0.51 & 1.66 & 5.54 & 1 & 4.652 \\
\hline Experiment No.2 & 1.85 & 1.32 & 6.06 & 1 & 3.952 \\
\hline Experiment No.3 & 1.33 & 0.70 & 6.17 & 1 & 3.690 \\
\hline Experiment No.4 & 1.38 & 0.94 & 8.44 & 1 & 3.812 \\
\hline Experiment No.5 & 1.65 & 1.20 & 8.52 & 1 & 3.710 \\
\hline
\end{tabular}

\section{Verification of RSM model}

The experiment with highest desirability based on the above solutions was performed. Table 6 shows the comparison of optimized response with responses obtained from experiments of highest desirability or lowest K/S. Since all the solutions are showing same desirability of 1 , experiment showing lowest K/S was performed to verify the model.

Table 6: Verification of RSM model.

\begin{tabular}{|c|c|}
\hline Sample & K/S \\
\hline Solution No.3 (Predicted) & 3.690 \\
\hline Solution No.3 (Experimental) & 3.681 \\
\hline
\end{tabular}

It can be observed that the predicted and experimental values of the responses of optimized fabric obtained by the solution for both the cases are nearby similar. Hence, it can be inferred that the appropriate empirical model equations have been developed for decolouration effect on indigo dyed denim fabric. This verifies the suitability and significance of the response surface BBM model to optimize the decolouration performance of ceric sulfate.

Table 7: Effect of Ceric sulfate on the physical and mechanical properties of indigo dyed denim fabric.

\begin{tabular}{|c|c|c|c|c|c|c|c|c|c|c|c|c|c|c|}
\hline \multirow{2}{*}{$\begin{array}{c}\text { Properties } \\
\text { Sample }\end{array}$} & \multirow{2}{*}{$\mathbf{K} / \mathbf{S}$} & \multirow{2}{*}{ GSM } & \multicolumn{2}{|c|}{$\begin{array}{c}\text { Tensile } \\
\text { Strength (Kgf) }\end{array}$} & \multicolumn{2}{|c|}{$\begin{array}{c}\text { Elongation } \\
(\%)\end{array}$} & \multicolumn{2}{|c|}{$\begin{array}{c}\text { Tear Strength } \\
\text { (Kgf) }\end{array}$} & \multicolumn{2}{|c|}{$\begin{array}{c}\text { Bending } \\
\text { Length }(\mathrm{cm})\end{array}$} & \multirow{2}{*}{$\begin{array}{l}\text { Crease } \\
\text { Recov- } \\
\text { ery } \\
\text { Angle } \\
\text { (deg.) }\end{array}$} & \multirow{2}{*}{$\begin{array}{c}\text { Water } \\
\text { Ab- } \\
\text { sorp- } \\
\text { tion } \\
(\%)\end{array}$} & \multirow{2}{*}{$\begin{array}{l}\text { Mois- } \\
\text { ture } \\
\text { Con- } \\
\text { tent } \\
(\%)\end{array}$} & \multirow{2}{*}{$\begin{array}{l}\text { Mois- } \\
\text { ture } \\
\text { Regain } \\
(\%)\end{array}$} \\
\hline & & & warp & weft & warp & weft & warp & weft & warp & weft & & & & \\
\hline Untreated & 5.486 & 285 & 68 & 34.5 & 43.5 & 17.5 & 95 & 93 & 4.6 & 2.8 & 150 & 125 & 7.3 & 7.4 \\
\hline $\begin{array}{l}\text { Treated } \\
\text { (Rinse) }\end{array}$ & 4.292 & 290 & 66 & 32.7 & 45.4 & 18 & 94 & 92.5 & 4.5 & 2.8 & 150 & 134 & 7.9 & 7.6 \\
\hline $\begin{array}{c}\text { *Treated } \\
\text { (Potassium } \\
\text { Permanga- } \\
\text { nate) }\end{array}$ & 3.675 & 292 & 64 & 32 & 47.2 & 20.4 & 86 & 83 & 4.1 & 2.6 & 174 & 145 & 8.6 & 8.2 \\
\hline $\begin{array}{l}{ }^{* *} \text { Treated } \\
\text { (Ceric Sul- } \\
\text { fate) }\end{array}$ & 3.681 & 295 & 62 & 31.3 & 48 & 22 & 87 & 85 & 4.2 & 2.7 & 177 & 145 & 8.6 & 8.3 \\
\hline
\end{tabular}

Apart from decolouration effect on denim fabrics, other physical and mechanical properties were also evaluated as illustrated in Table 7. The tensile and tear properties reduces which may be due to the disruption of cellulosic $\mathrm{H}$-bonds as well as some inevitable oxidation of cellulose due to the acidic condition maintained during the treatment. The extents of decrease in the tensile and tear strengths in both the directions of a fabric are found to be very less than $10 \%$ which is quite within the acceptable limit of commercial scale. The increase in total crease recovery angle and decrease in bending length are due to the weakening of structures as always seen as a consequence of wet processing. Such improvements in the wrinkle and bending properties of the treated denim are always desirable for the apparel wears. The water absorption, moisture content and moisture regain increases due to the catalytic hydrolysis of cellulose (fibres get loosened by spray treatment) which is essential for good breathability characteristics of any apparel. The fabric GSM measured after such treatment is found to be slightly higher than that of unwashed fabric which may be due to some amount of shrinkage occurring in the warp direction.

\section{Conclusion}

Worldwide trend for majority of denim fabrics is to have localized decolouration effect of vintage look conventionally produced by spray treatment with Potassium permanganate which is harmful due to the discharge of high amounts of Manganese disturbing the wellness of our ecosystem. Diving into the pool of sustainability, an attempt was made to locally decolourize the denim fabrics with a novel substance like ceric sulfate. Response surface methodology was adopted to optimize the parameters for such denim decolouration. At almost similar levels of concentration 
of Potassium permanganate, ceric sulfate could produce a desirable vintage look to an equivalent degree of decolouration on denim. Though there had been slight reduction unlikely to affect use in the tensile properties of ceric sulfate treated denim, there were simultaneous improvements with its wrinkle resistance and moisture absorbing capacities that could be considered as value additions to the decolouration effect. Thus, ceric sulfate could prove to be a new friend of the denim industries and to be taken up as an important area of research by the denim sectors for further commercialization and developments.

\section{References}

1. Ghoranneviss M, Shahidi S, Moazzenchi B, Anvari A, Rashidi A, et al (2007) Comparison between decolorization of denim fabrics with oxygen and argon glow discharge. Surf Coat Technol 201(9-11): 49264930.

2. (2012) Global denim market-production and consumption report. PR Web ebooks, pp. 1-4.

3. Kan CW (2014) Effect of enzyme washing on the tensile property of denim fabric. Advanced Materials Research 933: 175-178.

4. Rita HK (2012) Electrolytic ozone spray finishing system for denim wear. pp. 1-2.

5. Winkler F (2013) Jeans bleaching-advantages and risks of different bleaching processes. 3: 1-8.

6. Reidies AH (2002) Manganese compounds. Ullmann's Encyclopedia of Industrial Chemistry, Wiley-VCH, Weinheim, Germany.

7. Rodríguez Couto S (2012) Laccases for denim bleaching: An eco-friendly alternative. The Open Textile Journal 5: 1-7.
8. Yao JM, Wei SN (2013) Effects of potassium permanganate decoloration on denim shade. Advanced Materials Research 627: 190-194.

9. Maryan AS, Montazer M (2013) A cleaner production of denim garment using one step treatment with amylase/cellulase/laccase. J Cleaner Prod 57: 320-326

10. Cassee FR, Van Balen EC, Singh C, Green D, Muijser H, et al. (2011) Exposure, health and ecological effects review of engineered nanoscale cerium and cerium oxide associated with its use as a fuel additive. Crit Rev Toxicol 41(3): 213-229.

11. Binnemans K (2006) Applications of tetravalent cerium compounds. Handbook on the physics and chemistry of rare earths 36 : 281-392.

12. Tuckerman MM, Doctofsky N, Price R, Rake R, Ralph S, et al. (1964) Ceric sulfate as permanganate replacement in pharmacopeial assays. J Pharm Sci 53(6): 682-684.

13. Biranje SS, Nathany A, Mehra N, Adivarekar R (2015) Optimisation of detergent ingredients for stain removal using statistical modelling. J Surfactants Deterg 18(6): 949-956.

14. Maiti S, Jadhav A, Adivarekar RV (2017) Optimization of low temperature bleaching of cotton using statistical modelling. J Text Inst 108(6): 883892.

15. Mondal MIH, Khan MMR (2014) Characterization and process optimization of indigo dyed cotton denim garments by enzymatic wash. Fashion Text 1(19): 1-12.

16. Arjun D, Tejaswini LR, Hayavadana J, Susheel (2016) Effect of potassium permanganate finish on the properties of denim fabric. European Journal of Advances in Engineering and Technology 3(9): 28-32.

17. Prabaharan DMDM, Sadaiyandi K, Mahendran M, Sagadevan S (2016) Structural, optical, morphological and dielectric properties of cerium oxide nanoparticles. Mater Res 19(2): 478-482.
Creative Commons Attribution 4.0

International License

For possible submissions Click Here

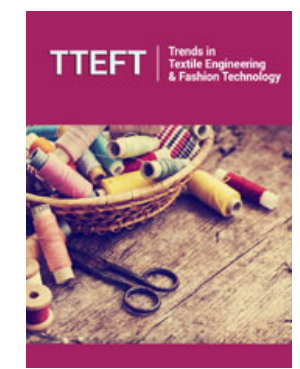

Trends in Textile Engineering \& Fashion Technology

\section{Benefits of Publishing with us}

- High-level peer review and editorial services

- Freely accessible online immediately upon publication

- Authors retain the copyright to their work

- Licensing it under a Creative Commons license

- Visibility through different online platforms 